\title{
AN ACCOUNT OF RECENT CAPTURES OF THE CALIFORNIA SEA- ELEPHANT, AND STATISTICS RELATING TO THE PRESENT ABUNDANCE OF THE SPECIES.
}

BY CHARLES H. TOWNSEND.

On October 14, 1884, I sailed from the port of San Diego, California, in the schooner Laura, of San Francisco, Captain Morrison, bound on a cruise in search of specimens of the sea-elephant (Macrorhinus angusti. rostris) for the Smithsonian Institution.

Previous to leaving San Francisco I had made special arrangements with the owners of the vessel there for the trip, which was undertaken under the direction of Professor Baird.

During a cruise of two months along the peninsula of Lower California, from San Diego to Magdalena Bay, 600 miles south of the United States and Mexican boundary, we explored carefully the intermediate coast-line and all the outlying islands, including Guadalupe, 160 miles off the coast, in about latitude $28045^{\prime}$.

As predicted by the captain of the Laura, the desired animals were found only at one place. This was a point on the mainland, 50 miles south of Cerros Island, and known to seal hunters as "Elephant Beach." The locality is indicated on the charts as San Cristobal Bay.

At this isolated and desolate place, on October 20, we discovered three young sea elephants sleeping on the sandy beach. As this locality had long been known to seal hunters as a favorite resort of the species, and is now known as the only remaining breeding rookery, the captain counseled that these three should for the present remain undisturbed, thinking that their presence on the rookery might induce larger animals to haul out there later in the season when we should return. After observing their actions on the beach and in the water for some time, we proceeded on our search farther south, leaving three of the men to camp near by and take possession of all animals that might appear in the mean time. Returning to this place a month later (November 18), we found but one of the three sea-elephants we had left there remaining, a female, which we killed. Three had been seen by the men on one occasion, but were probably the same ones we had left there.

Although we remained at San Cristobal Bay a week longer, no more animals appeared, and, after arranging with the captain to visit the place late in December and make a last attempt to procure the desired specimens for me, we sailed for San Diego, where I took the steamer for San Francisco.

While cruising about in search of sea-elephants we killed numbers of the black sea-lion (Zalophus californianus), and in preparing the skins and skeletons of these I had the help of the crew, and took special pains to instruct them in the preservation of such specimens. 
The last visit was made to the Elephant Beach December 31, and fifteen sea-elephants were killed and preserved in the best manner. There being no indications of others, the Laura proceeded to San Francisco. Of these fifteen animals only one was a male, which measured nearly 12 feet in length. The rest, with the exception of two pups, each about a week old and over 4 feet long, were females, averaging 10 feet in length.

Thirty or forty years ago the sea-elephant was found at many places on the coast between Santa Barbara Islands and Cape St. Lucas, but continual persecution has almost exterminated the species.

I conversed with a number of old men at San Diego and elsewhere, who were in the seal-oil business in its palmiest days, and learned that about the year 1860, the species became so scarce that their pursuit could no longer be carried on with protit, and that from about 1865 to nearly 1880 none of the animals were seen to the best of their knowledge, except stragglers observed at Guadalupe and Benita Islands. They were accordingly reported as extinct. My informants thought that, notwithstanding the fact of the sea-elephant having been found in limited numbers within the last few years, it was doomed to speedy extinction. I took pains to ascertain how many animals bad been found by the different vessels that have searched for them since their reappearance at their former haunts, and collected the information which is given in the following record:

1880. Schooner San Diego killed thirty sea-elephants at the Elephant Beach, at San Cristobal Bay, during the fall and winter.

1882. Schooner San Mateo, of San Pedro, killed forty sea elephants at Elephant Beach. Six live young ones were brought to San Francisco by a certain Captain Smith. What disposition was made of them was not ascertained.

1883. Schooner — , of San Francisco, Captain Lee, arriving at Elephant Beach October 9, found sixty sea-elephants. Of these the majority were young bulls; fourteen were bulls of large size, and there was one young one three weeks old. Other animals hauled ont there later in the season, and the schooner left, December 23, loaded with the oil of one hundred and ten sea-elephants over one year old.

Schooner San Diego found four good-sized bulls at Guadalupe Island. Date not ascertained.

1884. Sloop Liberty, of San Diego, Captain Morrison, arrived at the beach January 25, and killed thirty-three sea-elephants. Returned in March and killed sixty over one year old, leaving a few females and young undisturbed.

Schooner City of San Diego, of San Diego, arrived in May, and, finding no large animals, killed the females and young animals spared by the crew of the Liberty, forty in all.

Schooner Laura, of San.Francisco, Captain James Morrison, the writer being on board, arrived at San Cristobal Bay and saw three young sea-elephants, After unsuccessful searching elsewhere, returned, 
November 18, and killed a female, the only animal on the beach. After another trip as far north as San Diego returned again, December 31, and found fifteen animals, all of which were carefully preserved and are now in the Smithsonian Institution.

From this it would appear that this interesting and valuable animal has heavy odds to encounter in its struggle for existence. No sooner were the three hundred or more that had appeared during the years of their seclusion discovered than they were speedily made away with. That a pretty clean sweep had been made of them was evident from the meagre results of our own careful search, during which we not only inspected the coast-line, but circumnavigated the islands of the region both large and small. The herds of black sea-lions (Zalophus) inhabiting many places were also looked over for stray sea-elephants that might be among them. The great number killed at the old rookery at San Cristobal Bay in the fall and winter preceding our visit was, no doubt, the principal cause of their scarcity.

I had but little opportunity for observing their habits. Having had considerable experience with other species of seals during the summer, I was struck at once by the different mode of progression employed by these animals. Like the true Phocida, they do not throw their hind flippers forward in crawling, nor indeed lift them from the ground at all, but by arching the back the hind parts are dragged forward and used as a prop to serve in shoving the forequarters forward. Compared with it in this respect Eumetopias and Zalophus are animals of remarkable agility. Even when forced to exert themselves the hind limbs were never turned forwards, but literally trailed in the sand behind the body as if they were paralyzed. The black sea-lion especially is capable of making effective leaps and plunges when hurried towards the water, contrasted with which the retreat of the sea-elephant seemed a feeble crawl, the breast apparently never being raised from the ground.

old sealers told me that in all their experience with the sea-elephant they had never observed it swimming far out at sea as sea-lions often do ; in fact that they had never seen it outside the surf. This may have been due to the fact that they are less conspicuous in their actions. In protruding their heads above the surface, they are very quiet, making no blowing noises as sea-lions do. A favorite attitude in the water is to float about with the nose and hind flippers only above the surface.

The smaller animals are apparently liable to be attacked by sharks. The specimen we obtained November 18 (No. 233) was disfigured by a great gash on the rump, in which the print of shark's teeth was plainly evident. I was assured by the men that fully one-fourth of the females they had killed at San Cristobal Bay bore unmistakable traces of the teeth of sharks. The specimen referred to was found to be terribly infested with abdominal parasites, which I have never seen in any other pinniped. They were white thread-like worms, 3 or 4 inches in length. The eyes in the sea-elephant appear to be larger and more bulging than 
in their congeners. Where they are found in abundance they are easier to kill than the more agile seals. They also produce more oil in proportion to their size. They have had no chance during late years to attain large size, and it is doubtful whether they will ever again be found as large as that one which Captain Scammon found to measure 22 feet in length. He also mentions one measuring 18 feet, which yielded 210 gallons of oil. The largest bulls killed by Captains Lee and Morrison in the seasons of 1883 and 1884 averaged but 90 gallons of oil each. I found a weather-worn, but still well preserved, skull on the Elephant Beach which measures exactly 2 feet. This indicates an animal of very great size, having probably a length of 20 feet.

While at Magdalena Bay I learned of their former occurrence at San Hipolito Bay, which may be about half way between Cerros Island and Cape St. Lucas. From the great number of weather-worn skulls and other bones found at various places it is evident that their former abundance has not been overestimated. The beach at San Cristobal Bay was lined with bones, and we found them at many places on Cerros, Benita, and Natividad Islands. The new-born young that were met with in 1883-'84 were dropped at various times between November 1 and February 1.

The sea-elephant without doubt affects the vicinity of the roughest breakers. We seemed always to find its bones opposite places so rough that we could not land without danger. Captain Scammon mentions finding ruins of the stone huts built by the seal hunters of half a century ago. We met with these, too, but I should also add that we found many a nameless grave where the body of some unfortunate man, drowned in the surf, had found a last resting place when the sea gave up its dead. At San Cristobal Bay we often had our boats half filled with water in landing. It was not safe in fact to land through the surf there in any other boat than a dory, while we were compelled to anchor our schooner at Turtle Bay, nearly 20 miles distant. After these wettings some one had usually a harrowing tale of death by drowning to relate, and could adduce evidence thereto by pointing out some lonely grave.

DESCRIPTION OF A NEW SPECIES OF BOAT-BILLED HERON FROM CENTRAL AMERICA.

\section{BY RORERT RIDG WAY.}

-Cancroma zeledoni, sp. nov.

SP. CHAR.-Resembling C. cochlearia, (Linn.), but differing in having the neck and breast deep buff instead of ashy white; the under surface of the primaries ashy instead of white; the upper parts much deeper pearl-gray, and the crest far less developed.

Hab.-Central America, from southern and western Mexico to Veragua. 


\section{$2 \mathrm{BHL}$ Biodiversity Heritage Library}

Townsend, Charles Haskins. 1885. "An account of recent captures of the California sea-elephant, and statistics relating to the present abundance of the species." Proceedings of the United States National Museum 8(492), 90-93. https://doi.org/10.5479/si.00963801.492.90.

View This Item Online: $\underline{\text { https://www.biodiversitylibrary.org/item/52770 }}$

DOI: https://doi.org/10.5479/si.00963801.492.90

Permalink: https://www.biodiversitylibrary.org/partpdf/50967.

\section{Holding Institution}

Smithsonian Libraries

\section{Sponsored by}

Smithsonian

\section{Copyright \& Reuse}

Copyright Status: Public domain. The BHL considers that this work is no longer under copyright protection.

This document was created from content at the Biodiversity Heritage Library, the world's largest open access digital library for biodiversity literature and archives. Visit BHL at https://www.biodiversitylibrary.org. 